\title{
TRANSFORMATION IN THEOLOGY
}

Book Title:

Transformation theology:

Church in the world

\section{Book Cover:}

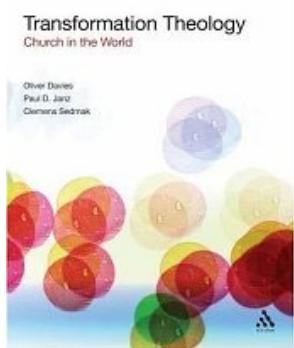

Authors:

Olivier Davies

Paul D. Janz

Clemens Sedmak

\section{ISBN:}

978-0-5670-3247-8

Publisher:

T \& T Clark, Edinburgh,

2007, pp. 179, \$39.95*

*Book price at time of Review

Review Title:

Transformation in theology

\section{Reviewer:}

Jaco Beyers ${ }^{1,2}$

Affiliations:

${ }^{1}$ Africa Institute for

Missiology, Pretoria,

South Africa

${ }^{2}$ Reformed Theological

College, University of

Pretoria, South Africa

email:

jaco.beyers@gmail.com

\section{Postal address:}

PO Box 14125, Lyttelton

0140, South Africa

How to cite this book review: Beyers, J., 2010,

'Transformation in theology', HTS Teologiese Studies/Theological Studies 66(1), Art. \#985, 1 page.

DOI: 10.4102/hts.v66i1.985

This review is available at:

http://www.hts.org.za

(c) 2010. The Authors.

Licensee: OpenJournals

Publishing. This work

is licensed under the

Creative Commons

Attribution License.
The book attempts to provide a responsible answer to the question of how the creed on the life, death and resurrection of Christ can still be confessed today, be believed, affirmed and be relevant for the church. The possibility of confessing the human and divine nature of Christ today is investigated. Does it still make sense for the church to confess these issues?

How does God reveal Jesus Christ today when He had revealed Christ 2000 years ago as a human being? Will God today choose the same way of revealing his Son? The book further addresses the question of how God will reveal Jesus Christ in future when He returns with the final judgment.

The authors work with the premise that theology today is practiced without emphasising the revelation through the incarnation of Christ. Theology today is practiced in abstract terms. Theology is obscured by linguistic and grammatical formulations. Abstractions, according to the authors, rarely provide solutions to questions. Abstractions further lead to subjective understanding which causes distance between individuals. Attention is then distracted from the incarnational revelation. The result is that theology becomes a science that is practiced estranged from the incarnation of Christ. The incarnation forms the foundation for the existence of theology.

A further implication is that theology becomes irrelevant to the church. The church professes the presence of Christ through his incarnation. When theology becomes separated from the incarnation, the church feels separated from theology.

The purpose of this book is to bridge the gap between academic theory (theology) and the community of faith (church) - hence the sub-title: Church in the World. This gap is bridged by attempting to present a theology of the reality of Christ in the world. The way in which theology is practiced must be reformed, hence the title: Transformation Theology.

The book is presented in three parts, with each of the authors taking responsibility for a particular part. Oliver Davies, Professor of Christian Doctrine at King's College London, was responsible for the first part on Doctrine. Doctrine can never be separated from its visible form. Therefore theology must endeavor to direct the thinking towards the incarnation, the visible.

Paul D. Janz, Lecturer in Philosophical Theology at King's College London, handled the part on Philosophy. This part of the book suggests a new methodology for practicing theology. Theology must admit its limitations and must constantly be investigating itself critically.

In the last part of the book Clemens Sedmak, FD Maurice Professor of Social and Moral Theology at King's College, London discusses Ethics. The point made is that theology must constantly be aware of the power of God that transforms human nature and behavior. Through the incarnation of Christ a new appeal is made on human existence in the world. This new community of transformed humans gathers as church and live directed towards the world. Sedmak applies the ethical appeal the Holy Spirit makes on Christians to the issue of hunger relief in the world.

This book is probably written with theologians as audience in mind. It is set in very fine print, which makes reading difficult. The importance of the book lies in the fact that it emphasises the connectedness between theological doctrine formulation and churchly life, which makes it essential reading for all theologians. 